\title{
"J" Rooting of Florida Strawberry Transplants ${ }^{1}$
}

John R. Duval, Elizabeth A. Golden ${ }^{2}$

Bare-root, green-top, strawberry transplants are hand planted into raised plastic mulched beds in order to establish fruiting fields in Florida. Transplants are set through holes in the plastic made by a machine that forms two rows of holes on the top of the bed. Holes measure approximately 3 in long by 1.6 inches wide by 4 inches deep, with the sides of the hole tapering together at the bottom. Transplants typically arrive from nurseries with roots in excess of 6 inches. This is much longer than the depth of standard planting holes; many transplants do not easily fit into planting holes. In the interest of speed, planters force the roots into the hole by laying the root system across the top of the hole and pushing it down at its midpoint. This results in the roots being forced together in a bunch and having a "J" shape in the hole after it is closed. In some cases root tips are left exposed above the soil and plastic mulch.

Immediately following transplanting, overhead irrigation is applied 8-10 hr/day for 10-14 days to reduce heat and moisture stress to the plants while they are regenerating a viable root system. According to Galletta and Himelrick (1990) the root system is reestablished within 2 to 3 months of transplanting. Quick establishment of strawberry transplants in Florida is essential because early season yields can determine the success of the growing season. This study was implemented to determine if current planting technique adversely affects strawberry performance.

A complete randomized block design replicated four times was used to determine whether "J" rooting affects strawberry plant performance. Sweet Charlie and Oso Grande strawberry transplants produced in Nova Scotia, Canada were shipped to the Gulf Coast Research and Education Center-Dover. Treatments consisted of transplants set in the conventional planting with roots in a " $\mathrm{J}$ " root shape, and transplants set in holes that were enlarged using a small hand spade to accommodate the entire length of the transplant's root system in a vertical orientation (straight rooted). All plants were set with the crown at the soil level. Transplants were planted on 21 October 1999 in a double row spaced 12 inches apart with 15-inch row spacing on a plastic mulched bed. Following industry standards, the plots were irrigated for 10 hours a day for 10 days for establishment. Plant fertilization and pest control were maintained in accordance with University of Florida IFAS Cooperative Extension Service recommendations (Maynard and Olson, 2000).

First harvest occurred on 17 December 1999. Thereafter, strawberries were harvested twice weekly

1. This document is HS990, one of a series of the Horticultural Sciences Department, Florida Cooperative Extension Service, Institute of Food and Agricultural Sciences, University of Florida. Original publication date July 30, 2004. Visit the EDIS Web Site at http://edis.ifas.ufl.edu.

2. John R Duval, assistant professor, Elizabeth A Golden, biological scientist, Gulf Coast Research and Education Center, Dover, Florida Cooperative Extension Service, IFAS, University of Florida, Gainesville, FL 32611

The Institute of Food and Agricultural Sciences (IFAS) is an Equal Employment Opportunity - Affirmative Action Employer authorized to provide research, educational information and other services only to individuals and institutions that function without regard to race, creed, color, religion, age, disability, sex, sexual orientation, marital status, national origin, political opinions or affiliations. For information on obtaining other extension publications, contact your county Cooperative Extension Service office. Florida Cooperative Extension Service / Institute of Food and Agricultural Sciences / University of Florida / Larry R. Arrington, Interim Dean 
until 9 March 2000 for Sweet Charlie and until 23

March 2000 for Oso Grande. Sweet Charlie harvest

was ended early to mirror industry practice. Data

concerning plant mortality, number of marketable

and cull fruit, weight of marketable fruit, and fruit

disease incidence were recorded. Data were

separated into monthly and seasonal totals and

analyzed using SAS statistical software (SAS

Institute, Cary, NC).

No significant treatment $\mathrm{x}$ variety interactions were detected. No significant differences were detected for marketable yield or any other variable during any period for either variety. In an additional study performed at the Dover Research center, (Duval and Golden, 2002), 60\% of the root mass of each bare-root, green-top transplant was removed immediately prior to transplanting. Again, there were no significant effects on plant performance in the Florida production system. This study suggests that the treatment of root systems while planting is not critical when recommended irrigation establishment practices are followed. 